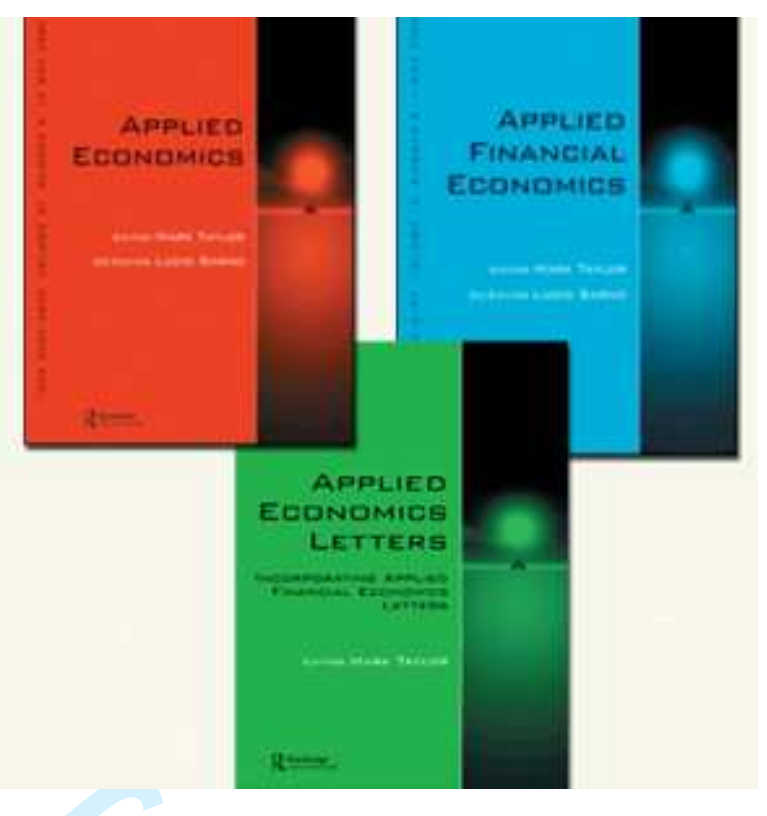

\title{
Investment Behaviour in Individual Non-Transferable Quota Systems
}

\begin{tabular}{|c|c|}
\hline Journal: & Applied Economics \\
\hline Manuscript ID: & APE-2009-0147 \\
\hline Journal Selection: & Applied Economics \\
\hline $\begin{array}{r}\text { Date Submitted by the } \\
\text { Author: }\end{array}$ & 03-Mar-2009 \\
\hline Complete List of Authors: & $\begin{array}{l}\text { Jensen, Frank; University of Copenhagen, Institute of Food and } \\
\text { Resource Economics } \\
\text { Andersen, Jesper; University of Copenhagen, Institute of Food and } \\
\text { Resource Economics } \\
\text { Jensen, Carsten; University of Copenhagen, Institute of Food and } \\
\text { Resource Economics }\end{array}$ \\
\hline JEL Code: & $\begin{array}{l}\text { D21 - Firm Behavior < D2 - Production and Organizations < D - } \\
\text { Microeconomics, D24 - Production|Capital and Total Factor } \\
\text { Productivity|Capacity < D2 - Production and Organizations < D - } \\
\text { Microeconomics, E22 - Capital|Investment (including } \\
\text { Inventories)|Capacity < E2 - Consumption, Saving, Production, } \\
\text { Employment, and Investment < E - Macroeconomics and Monetary } \\
\text { Economics }\end{array}$ \\
\hline Keywords: & Fisheries, Investment \\
\hline
\end{tabular}




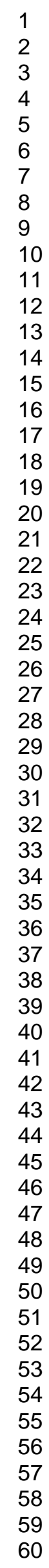

ScholaroNE"

25

26

27

29

30

32

33

34

35

36

39

40

41

42

44

45

46

47

48

49

50

52

53

54

55

57

58

59

60 


\title{
Investment Behaviour in Individual Non-Transferable Quota Systems
}

\author{
By \\ Frank Jensen, Jesper Andersen and Carsten Lynge Jensen \\ Institute of Food and Resource Economics \\ University of Copenhagen \\ Rolighedsvej 25 \\ 1958 Frederiksberg \\ Denmark \\ e-mail: fje@foi.dk, jla@foi.dk and clj@foi.dk \\ Corresponding authors: Frank Jensen
}

\begin{abstract}
This paper studies investment behaviour for the Danish demersal fishery in the North Sea. For the study period, this fishery is regulated by variants of individual non-transferable quotas. It is shown that interest rates and capital stocks are primary determinants of investments. Another conclusion is that an aggregated model based on the whole fleet gives identical results to models based on individual fleets (disaggregated models) for trawlers and Danish Seiners. However, for netters and other vessels the aggregated and disaggregated models yield different results. In addition, the variance of the estimated parameters is lower in the disaggregated models. This result arises because vessels in the disaggregated models are more homogeneous. Furthermore, investment in machinery, electronics and vessels are governed by one year-lagged variables, while investment in gears is governed by present variables for the Danish demersal fishery in the North Sea.
\end{abstract}




\section{Introduction}

The problem of management of fisheries is well-known. Management of fisheries is necessary because each individual fisherman disregard the effect on other fishermen's harvest throughout the stock (see for example Brown (1974)). Within practical fisheries management non-transferable quotas (IQs) is extensively used (see Wilen (2000)). Theses IQs exist in many variants. Denmark has used rations for the main part of their fisheries. Rations are an allocation of IQs on shorter time periods. The purpose of IQs is to limit harvest in order to protect fish stocks. Economic theory has primarily focussed on the gains of making quotas transferable (see Arnason (2008)). Less attention have been devoted to the issue of what are the main drives for investments in fisheries. Identifying these drivers is important in general but also in an IQ system because it has an impact on the size of the IQ/ration that is allocated to the individual fishermen.

The most well-known work on investment was developed in the 60s (Smith (1968) and (1969)) and 70s (Clark et al (1979)). Clark et al (1979) combine the work by Clark and Munro (1975) on the use of capital theory to analyse investment in stocks with theories of investment in physical capital. However, there are only a few empirical studies of drivers of investment in fisheries. The topic of fishing capacity has, on the contrary, received much attention. A good overview can be found in Kirkley and Squires (1979). However, given that capacity and investment is closely linked, it is surprising that there only is little empirical literature on investments. Previous empirical work of relevance for the current study includes Wilen (1976). The focus in Wilen (1976) is on the estimation of parameters measuring the speed at which fleets respond to changes in the average profitability in terms of vessel entry and exit. The dynamics of the North Pacific fur seal fishery is studied and Wilen (1976) develops a model that describes the cycles of the open-access fishery in terms of stock dynamics, harvesting and profits.

The purpose of the present paper is to analyse investment in an IQ system covering the Danish demersal fishery in the North Sea as an empirical case. We ask the question of what drives investments. It is shown that interest rates and capital stocks are primary determinants of investment in this fishery. To arrive at this conclusion we use a panel dataset covering the years from 1996 to 2005. A surprising conclusion is that for some of the Danish demersal fleet in the North Sea an aggregated model based on the whole fleet gives identical results to models based on individual fleets (disaggregated models). This conclusion holds for trawlers and Danish Seiners. However, the result does not hold for netters and other vessels. Thus, there may be arguments for estimating disaggregated investment models. 
In many fisheries, it is not unusual that several vessels are controlled and owned by the same owner. In this case investments should be analysed at firm level rather than vessel level. However, in our case we only have included firms where all effort is concentrated at one vessel. Thus, the difference between vessel level and firm level disappear. Each owner only uses one vessel in the fishing activity.

The present work is organised as follows. Section 2 sketches the theory behind the empirical analysis of fisheries, while section 3 presents the regulatory approach and the data. In section 4 the empirical analysis is presented and section 5 concludes the paper.

\section{Theory}

There is a vast economic literature on investment behaviour. The empirical literature typically uses econometric models to explain investments. Traditionally, empirical analysis of investment behaviour of a firm has been based on the neoclassic investment model. Firms are assumed to maximise the present value of future profits. Delivery lags, adjustment costs and vintage effects are absent and capital depreciates at a constant rate. Firms are assumed to face a user cost of capital that is independent of the financial structure of the firm.

The neoclassic investment model has been criticised for several reasons and other models have been proposed that deal with various issues that have been raised. Many of these models have several things in common. Typical assumptions and elements are:

1. The firm seeks to maximise discounted value of cash flows over an infinite horizon

2. Output is given by a production function which relates the level of production to variable inputs, capital and possible technological shocks

3. Capital dynamics are given by $K_{t}=I_{t}+(1-\alpha) K_{t-1}$, where $I_{t}$ is investment in period $t, K_{t}$ is the capital stock in period $t$ and $\alpha$ is the rate of capital depreciation

4. There might be adjustment costs to changing the capital stock

5. Estimated equations are derived from the optimising conditions of the constrained dynamic maximisation problem 
Most investment behaviour analysis in the literature study investment decisions within traditional industries consisting manufacturing firms. The production process of fishing firms differs in several respects which imply that we have to modify the model used. One factor that complicates the study of investment behaviour in fisheries is the fact that the production level of the firm in most cases is restricted by quotas and effort regulations. The fishing quota of a firm will affect the value of the capital stock and, thereby, the investment decision. In this paper we study investment decisions of a fishing firm within an IQ system. This is meant to capture the case of rations which is used extensively in Danish fisheries regulation. In the present paper, we modify a model for transferable quotas by Nøstbakken (2009) to analyse IQs.

The vessel, which is a price taker in all relevant markets, seeks to maximise the net present value of future cash flows. With IQs the cash flow in period $t, C F_{t}$, can be expressed as (see Clark and Munro (1975)):

$$
C F_{t}=p_{t} Y_{t}-w_{t} L_{t}-c\left(I_{t}\right)
$$

where

$$
\begin{aligned}
& p_{t} \text { is the price of fish } \\
& Y_{t} \text { is the quantity landed } \\
& L_{t} \text { is the variable input } \\
& w_{t} \text { is the price of the variable input } \\
& c\left(I_{t}\right) \text { is a function that gives the cost of investment as a function of investment }
\end{aligned}
$$

$c\left(I_{t}\right)$ is not necessary linear in $I_{t}$. This allows for non-malleable capital. Empirical studies indicate that the price of fishing capital is higher for investments than for disinvestments. Note that all righthand side variables in (1) can be expressed as vectors; i.e. the variables may have more than one argument.

The net present value of future cash flows must be maximised subject to several constraints. The dynamics of physical capital are given by (see Jorgensen (1971)):

$$
K_{t}=I_{t}+(1-\alpha) K_{t-1}
$$


The IQ restriction is given by:

$$
Y_{t} \leq Q_{t}
$$

where $Q_{t}$ is the IQ. Note that there is no depreciation of quotas.

The harvest technology of the firm is given by a production function which relates the level of inputs to outputs:

$$
Y_{t}=F\left(L_{t}, K_{t}, S_{t}\right)
$$

where $S_{t}$ is the stock size.

Finally stock size is assumed to be stochastic variable in the model. This is assumed in order to keep the model tractable as we avoid explicitly modelling the dynamics of stocks as a function of harvest. $S_{t}$ is assumed to follow a known Markov process. We assumed that $S_{t}$ is mean reverting (see Reed (1979)):

$$
S_{t+1}=S_{t}+\eta\left(\bar{S}-S_{t}\right)+z_{t}
$$

where

$$
\begin{aligned}
& \eta \text { is the speed of reversion } \\
& \bar{S} \text { is the level of which the stock tends to revert to. }
\end{aligned}
$$

For a regulated fishery $\bar{x}$ can be thought of as the desired stock level as defined by regulator. $z_{t}$ is a normal distributed random variable. Equation (5) captures that the actual stock varies around the mean stock due to stochastic variation.

With this in place the dynamic optimisation problem of the firm may be formulated as:

$$
\operatorname{Max} E\left[\sum_{t=1}^{\infty} \beta^{t}\left(p_{t} Y_{t}-w_{t} L_{t}-c\left(I_{t}\right)\right]\right.
$$

s.t. 


$$
\begin{aligned}
& K_{t}=I_{t}+(1-\alpha) K_{t-1} \\
& Y_{t} \leq Q_{t} \\
& Y_{t}=F\left(L_{t}, K_{t}, S_{t}\right) \\
& S_{t+1}=S_{t}+\eta\left(\bar{S}-S_{t}\right)+z_{t}
\end{aligned}
$$

where

$$
\beta \text { is the discount factor }
$$

$E$ is an expectation over possible realisations of stock

It is reasonable to assume that the firm maximises the expected discounted value of future cash flows subject to several restrictions. To obtain this the firm chooses their investments in physical capital which is equivalent to maximise over $K_{t+1}$. The second control variable is the level of variable input $L_{t}$. The problem has two state variables, the level of capital, $K_{t}$ and the biomass of the resource stock $S_{t}$.

The maximisation problem can be solved using dynamic programming. The Bellman equation of the problem is (see Conrad and Clark (1991)):

$$
\begin{aligned}
& v\left(K_{t}, Q_{t}, S_{t}\right)=\operatorname{Max}\left[p_{t} F\left(L_{t}, K_{t}, S_{t}\right)-w_{t} L_{t}-c\left(K_{t+1}-(1-\alpha) K_{t}\right)+\right. \\
& \left.\beta E\left(V\left(K_{t+1}, Q_{t+1}, S_{t}\right)\right)-\mu_{t}\left(F\left(L_{t}, K_{t}, S_{t}\right)-Q_{t}\right)+\lambda_{t}\left(S_{t+1}-S_{t}-\eta\left(\bar{S}-s_{t}\right)-z_{t}\right)\right]
\end{aligned}
$$

where $\mu_{t}$ and $\lambda_{t}$ is shadow prices.

The first-order conditions characterising the optimal solution are presented in the following (see Clark (1991)). The condition for variable input becomes: 


$$
\left(p_{t}-\mu_{t}\right) \frac{\partial F}{\partial L_{t}}=w_{t}
$$

If the quota restriction is non-binding $\left(\mu_{t}=0\right)$ the optimality condition states that marginal revenue equal marginal cost. Is the quota binding $\left(\mu_{t}>0\right)$ this reduces the marginal revenue from an increase in $L_{t}$. Notice that the optimal value of $L_{t}$ is stated in terms of $K_{t}, S_{t}$ and $Q_{t}$.which are all assumed known when the agent chooses variable inputs.

Similar, the first-order condition for $K_{t+1}$ can be stated as:

$$
\frac{\partial c}{\partial K_{t+1}}=\beta \frac{\partial V}{\partial K_{t+1}}
$$

Thus, the marginal costs of increasing capital are the investment costs and must equal the marginal revenue in terms of increased expected value of the operation. In addition, the dynamic constraints and fish stocks together with the quota constraint must be satisfied. In order to solve the problem, functional forms must be specified. However, we may state the optimal solution for variable inputs and investments as:

$$
\begin{aligned}
& L_{t}=L\left(K_{t}, K_{t-1}, Q_{t}, Q_{t-1}, S_{t}, S_{t-1}, Y_{t}, I_{t}, w_{t}, p_{t}, \beta, C F_{t}\right) \\
& I_{t}=I\left(K_{t}, K_{t-1}, Q_{t}, Q_{t-1}, S_{t}, S_{t-1}, Y_{t}, L_{t}, w_{t}, p_{t}, \beta, C F_{t}\right)
\end{aligned}
$$

Without specifying functional forms and finding analytical solutions of the model, it is clear that an increase in output prices and a decrease in input prices would strengthen the vessels incentive to invest. In addition, a large stock size increases investments. The same conclusion applies to the capital stock. Furthermore, a large quota increases investments. 
3 The regulatory framework and the data.

At the overall level, the catch possibilities for the primary part of Danish fisheries are regulated within a quota system. The quota levels are set in agreement with the Total Allowable Catches (TAC) determined at the EU level. For Denmark, more than 35 species are quota regulated for different fishing areas. Thus, in total more than 120 quotas restrict the catch possibilities for the Danish fishermen.

The catch possibilities of the Danish demersal fishery in the North Sea are regulated using rations or IQs. The individual quota levels are determined using vessel length. Through the year, these levels are changed regularly depending on the exploitation level and distribution of fishing activity during the year. So-called "annex 6" announcements from the Danish Directorate of Fisheries is used to manage this detailed quota exploitation during the year.

Data have been obtained from the Danish Account Statistics of Fisheries and are based on annual surveys of costs and revenues of fishing firms. In addition to costs and revenues, the data set contains information about other variables such as catch and values by species, physical vessel characteristics and capital value of the vessel. Data on investments and capital values are available from 1996-2005. In addition, we have data on individual vessels and, therefore, perform a panel data analysis.

The data set covers vessels fishing in all Danish marine areas. Therefore, the vessels in the whole data set are very heterogeneous and working with heterogeneous vessels may pose problems for identifying drivers for investment behaviour. Thus, we restrict attention to the demersal fishery in the North Sea. This fishery is defined according to three criteria. First, at least $70 \%$ of the fishing effort of a vessel must be allocated to the North Sea. Second, no more than $20 \%$ of the harvest value must be obtained by catching industrial species, herring and mackerel. Third, all fishing effort must be allocated to one vessel.

For the demersal fishery in the North Sea, besides a total investment level, we have data on investments within the following categorises:

- vessel

- machinery

- electronics

- gears 
Investments are defined as the cost of new equipment as they appear in account statistics.

With respect to capital we have no direct measure of this variable. We, therefore, use the insurance value. The insurance value is defined as the total cost of the insurance. We also need a measure of the interest rent. In the data set we have a capital measure (the insurance value) and interest expenditures. Interest expenditures are defined as total interest costs. The interest rent can now be calculated as interest costs shared by insurance value. With respect to output prices and quantities we have information about several species. We, therefore, choose to construct indices for these variables. The index chosen is the Fisher index. We also need information about the amount of labour and the wage rate. However, in the data set only total wage costs are available. We, therefore, choose this measure for labour.

Table 1 gives an overview over number of observations and mean values for investment, capital, output prices and total wage costs.

Table 1: Descriptive statistics for the demersal fishery in the North Sea, 2005

\begin{tabular}{|l|l|l|l|l|}
\hline $\begin{array}{l}\text { Number of } \\
\text { observations }\end{array}$ & $\begin{array}{l}\text { Mean total } \\
\text { investment costs } \\
\text { DKK }\end{array}$ & $\begin{array}{l}\text { Mean capital } \\
\text { stock } \\
\text { DKK }\end{array}$ & $\begin{array}{l}\text { Mean output } \\
\text { prices } \\
\text { Index }\end{array}$ & $\begin{array}{l}\text { Mean wage costs } \\
\text { DKK }\end{array}$ \\
\hline 529 & 474,691 & $6,149,968$ & 0.792 & 1.159 .893 \\
\hline
\end{tabular}

In total we have 529 observations. The mean capital stock and wage costs are reasonable high. Mean investment is on 474.691 DKK.

Figures 1 shows the average annual profit for the demersal fishery in the North Sea. 
Figure 1: Average annual profit.

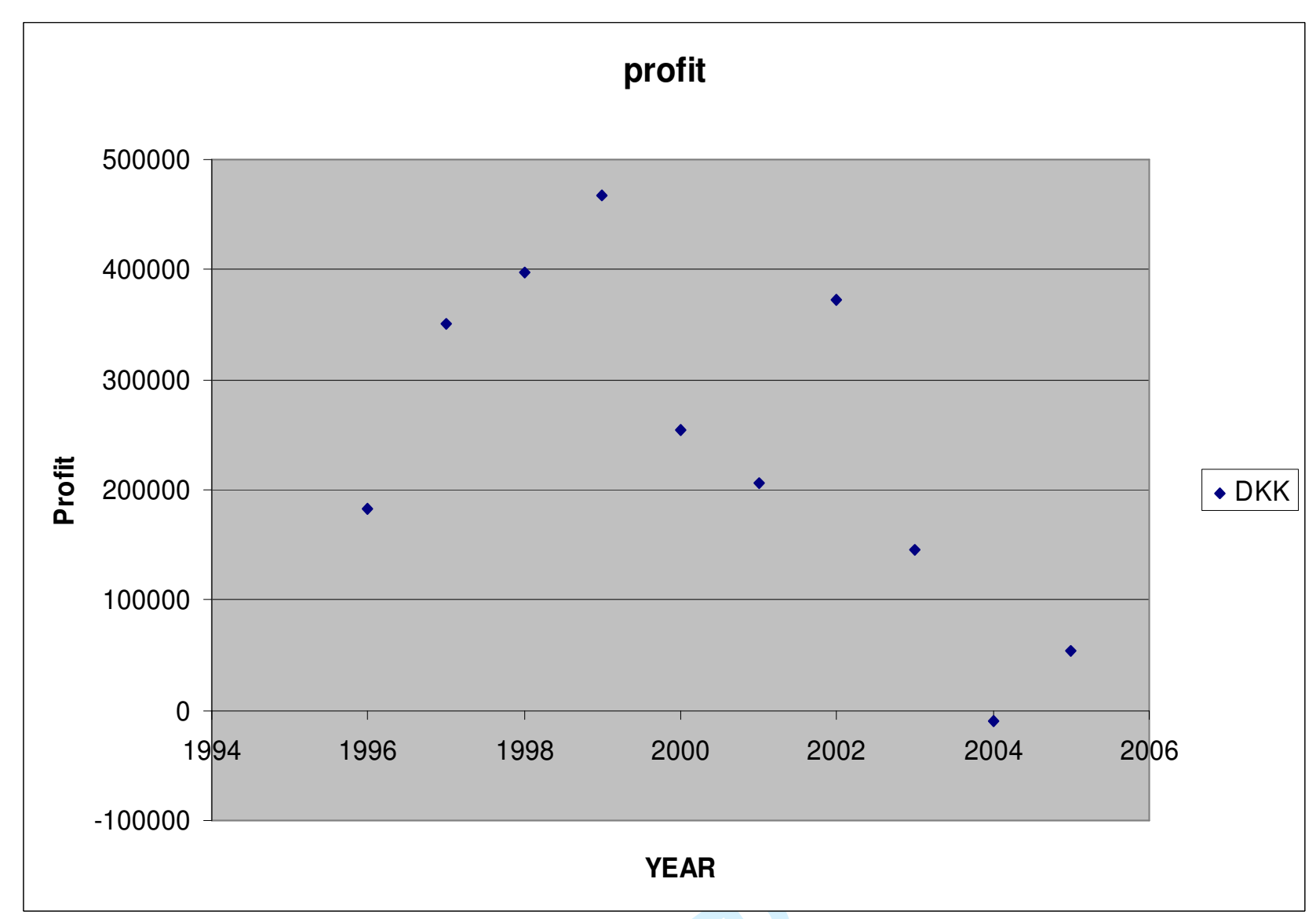

From 1996 to 1999 the profit is increased followed by a decrease in profit. In 2002, the profit increase again but from 2003 and onwards the profit is at a very low level. The profit in the demersal fishery in the North Sea follows the development in the cod stock (see Anon (2007)).

\section{The empirical analysis \\ 4.1. The empirical models}

To investigate drivers of investments, the panel of vessel data over the period 1996-2005 for the demersal fishery in the North Sea is investigated. We use two empirical models. The first is a linear approximation of (12) given as:

$$
I_{i t}=\alpha+\beta X_{i t}+\rho Z_{i t}+\varepsilon_{i t}
$$

The other specification is a logarithmic specification of (12): 


$$
\ln I_{i t}=\ln \alpha+\beta \ln X_{i t}+\rho \ln Z_{i t}+\varepsilon_{i t}
$$

where $X_{i t}$ is a vector of explanatory variables and $Z_{i t}$ is a vector of other variables that influences investments. $\alpha$ is a constant term, $\beta$ is a vector of coefficients for explanatory variables and $\rho$ is a vector of coefficients for other variables. In principle all variables included in (12) shall be included in $X_{i t}$. This implies that we shall take account for input prices and quantities, output prices and quantities and quotas. The advantage of the logarithmic specification is that the coefficient in front of a variable can be interpreted as an elasticity.

In connection with estimation of (13) and (14) a problem occurs. Some of the variables is (12) are endogenous in the sense that they are correlated with the error term. When a variable is correlated with the error term biased estimates of the parameter in front of the variable arise. This would be the case for $K_{t}, Y_{t}$ and $L_{t}$ because these variables are determined in the theoretical model. The normal solution to problems with endogeneity is to use instrumental variables. However, our data set does not allow this possibility. We must, therefore, decide to include or not include the variables. With respect to capital we have decided to include this variable because it is an important determinant for investments. After all investments is an addition to the capital stock. With regard to the index for output quantities we have chosen to exclude this variable because we think that the contribution to explaining investments is low. With respect to labour we only have information about total wage costs. However, total wage expenditures on labour will be endogenous because the quantity of labour is endogenous. We therefore exclude total wage cost in the estimation. Table 2 gives an overview over included variables.

Table 2: Included explanatory variables

\begin{tabular}{|l|l|}
\hline Name & Description \\
\hline Tonnage & The total tonnage of the vessel \\
\hline Year & The year the vessel is build \\
\hline Capital & The total insurance value \\
\hline Price & A Fisher price index \\
\hline Interest & The interest rate \\
\hline Profit & The total profit \\
\hline$D_{\text {year }}$ & Dummy variables for the year \\
\hline$D_{\text {type }}$ & Dummy variables for the type of the vessel \\
\hline
\end{tabular}


When the logarithmic model is used the variable name ln(name) is used. For example, we use $\ln$ (tonnage). Note that we can not include profit in the logarithmic model. This is due to the fact that profit is negative for some observations. Below we also estimate models with lags. The notation when using lags is name ${ }_{-1}$. For example for the interest rate lagged one period we write interest ${ }_{-1}$. In a logarithmic specification this would be $\ln (\text { interest })_{-1}$.

We conduct experiments with four types of models. An overview of the models is given in Table 3 .

Table 3: The four analysed models

\begin{tabular}{|l|l|l|}
\hline & Estimation of (13) & Estimation of (14) \\
\hline No lags & Model 1 & Model 2 \\
\hline Lags & Model 3 & Model 4 \\
\hline
\end{tabular}

Thus, model 1 and 2 are without lags while model 3 and 4 are with lags. Note that we have lagged all explanatory variables in model 3 and 4 . Remark, also, that we have estimated the different models for all five investment categories mentioned in section 3.1. Thus, we estimate models for total investment, investment in vessels, investment in machinery, investment in electronics and investment in gears.

We estimate both aggregated and disaggregated models. In the aggregated models we do not distinguish between the different vessels types. Therefore, we include $\mathrm{D}_{\text {type }}$. The vessel categorises is trawlers between 10-18 meters ( $\left.D_{t 10-18}\right)$, trawlers between 18-24 meters $\left(D_{t 18-24}\right)$, trawlers between 24-40 meters $\left(D_{t 24-40}\right)$, trawlers over 40 meters $D_{t>40}$, Danish Seiners $\left(D_{s}\right)$, netters $\left(D_{N}\right)$ and other vessels $\left(D_{0}\right)$. In the disaggregated models, we estimate separate equations for each vessel category. In both the aggregated and disaggregated models we estimate all models in Table 3.

\subsection{Estimation results \\ 4.2.1. Aggregated models}

We start by noticing that we have no problems with autocorrelation and heteroscedasticity in the models reported below. In all cases the Durbin-Watson test is below 0.48 and the White test is below 10.4. Therefore, we can estimate the models with OLS. The absence of autocorrelation can be explained with the yearly dummy while homoscedasticity is the case because of the dummy for type.

In order to interpret the results we distinguish between: 
- Investment in gears.

- Other investments.

The criteria for choosing between models are that the sign in front of the explanatory variables is reasonable and that $\mathrm{R}^{2}$ is high.

For investment in gears in the demersal fishery in the North Sea, model 2 performs best. An overview over the results is given in table 3 .

Table 4: Results for investment in gears for the demersal fishery in the North Sea

\begin{tabular}{|l|l|}
\hline & Parameter and in parenthesis t-value \\
\hline Constant term & $13.46(0.56)$ \\
\hline Ln(tonnage) & $0.08(1.01)$ \\
\hline Ln(year) & $-0.99(-0.15)$ \\
\hline Ln(capital) & $0.10(4.71)$ \\
\hline Ln(price) & $0.03(1.04)$ \\
\hline Ln(interest) & $-0.62(-5.86)$ \\
\hline$D_{1996}$ & $0.11(1.11)$ \\
\hline$D_{1997}$ & $0.13(1.39)$ \\
\hline$D_{1998}$ & $0.09(0.75)$ \\
\hline$D_{1999}$ & $0.16(1.55)$ \\
\hline$D_{2000}$ & $0.02(0.17)$ \\
\hline$D_{2001}$ & $-0.01(-0.29)$ \\
\hline$D_{2002}$ & $0.11(0.87)$ \\
\hline$D_{2003}$ & $0.02(0.13)$ \\
\hline$D_{2004}$ & $0.06(0.64)$ \\
\hline$D_{t 18-24}$ & $-0.21(-1.79)$ \\
\hline$D_{t 24-40}$ & $-0.69(-7.15)$ \\
\hline$D_{t 10-18}$ & $-0.37(-2.15)$ \\
\hline$D_{t} 40$ & $-1.18(-2.99)$ \\
\hline$D_{s}$ & $0.09(0.87)$ \\
\hline$D_{N}$ & $1.64(6.14)$ \\
\hline$R^{2}$ & 0.52 \\
\hline$D_{1}$ wrbin-Watson test & 0.48 \\
\hline$W_{1}$ test & 10.4 \\
\hline & \\
\hline
\end{tabular}

In Table 4, the numbers in parenthesis is t-values. From $\mathrm{R}^{2}$ we see that the model performs reasonable. The sign in front of $\ln ($ interest) is negative as we would expect. This implies that a high interest rate implies low investments in gears. The sign in front of the other explanatory variables is also as we would expect. The t-values indicate that capital and interest is significant at a $5 \%$ level. 


\begin{abstract}
Therefore, judged by the t-values the main drivers of investment behaviour are capital and interest rate. Tonnage, year and price are all insignificant and for this reason they do not contribute much when explaining investments in gears. For trawlers the parameter in front of the dummy variable is negative while the parameter is positive for netters and Danish Seiners. This implies that trawlers have a lower level of investments compared to Danish Seiners and netters.

That investment in gears is explained in a model without lags are not surprising. Gears are necessary for the fishing activity and if something are wrong with the gears the owner must invest immediately. Thus, it seems reasonable that model 2 performs best for gears. With respect to the other investment categorises regression analysis has been performed for each separate category. However, it turned out that the highest explanatory power and most reasonable signs were obtained by aggregating the investment categories into one category. Thus, we estimate on investments in other things than gears. For this investment, model 4 performs best. Table 5 reports the results.
\end{abstract}


Table 5: Results for investment in other things than gear

\begin{tabular}{|c|c|}
\hline & Parameter and in parenthesis t-value \\
\hline Constant term & $-41.1(-0.59)$ \\
\hline Ln(tonnage) & $0.47(0.78)$ \\
\hline Ln(year) & $-0.10(-1.01)$ \\
\hline Ln(capital) & $0.01(0.99)$ \\
\hline Ln(price) & $0.09(0.87)$ \\
\hline Ln(interest) & $-0.15(-0.18)$ \\
\hline Ln(tonnage $)_{-1}$ & $1.09(2.03)$ \\
\hline Ln(year $)_{-1}$ & $-0.49(-0.99)$ \\
\hline Ln(capital) -1 & $0.23(7.07)$ \\
\hline $\operatorname{Ln}(\text { price })_{-1}$ & $0.09(0.97)$ \\
\hline Ln(interest) $)_{-1}$ & $-0.30(-3.01)$ \\
\hline $\mathrm{D}_{1996}$ & $0.09(0.74)$ \\
\hline $\mathrm{D}_{1997}$ & $0.06(0.80)$ \\
\hline $\mathrm{D}_{1998}$ & $0.11(1.09)$ \\
\hline $\mathrm{D}_{1999}$ & $0.07(1.09)$ \\
\hline $\mathrm{D}_{2000}$ & $-0.14(-1.05)$ \\
\hline $\mathrm{D}_{2001}$ & $0.18(1.59)$ \\
\hline $\mathrm{D}_{2002}$ & $0.19(1.13)$ \\
\hline $\mathrm{D}_{2003}$ & $-0.13(-2.75)$ \\
\hline $\mathrm{D}_{2004}$ & $0.15(1.17)$ \\
\hline $\mathrm{D}_{\mathrm{t} 18-24}$ & $-0.24(-2.24)$ \\
\hline $\mathrm{D}_{\mathrm{t} 24-40}$ & $-0.79(-4.15)$ \\
\hline $\mathrm{D}_{\mathrm{t} 10-18}$ & $-0.11(-1.12)$ \\
\hline $\mathrm{D}_{\mathrm{t}>40}$ & $-1.15(-6.12)$ \\
\hline $\mathrm{D}_{\mathrm{s}}$ & $1.04(2.18)$ \\
\hline $\mathrm{D}_{\mathrm{n}}$ & $1.03(1.17)$ \\
\hline $\mathrm{R}^{2}$ & 0.61 \\
\hline Durbin-Watson test & 0.34 \\
\hline White test & 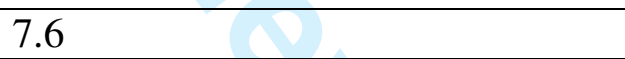 \\
\hline
\end{tabular}

Judged by $\mathrm{R}^{2}$ the model performs well and the signs in front of the explanatory variables are as expected. In particular, that the sign in front of $\ln (\text { capital })_{-1}$ is positive and the sign in front of $\ln (\text { interest })_{-1}$ is negative. $\ln (\text { tonnage })_{-1}, \ln (\text { capital })_{-1}$ and $\ln (\text { interest })_{-1}$ is significant at a $5 \%$-level. Trawlers invest less than the category other vessels while Danish Seiners and netters invest more. The significant parameters indicate that the variables gives a contribution to explaining investments and, therefore, that the variable is a main driver of investments. An implication of this is that lagged variables are the main drivers for investment in other things than gears. That lagged variables explain investments can be explained by the fact that investment in machinery, vessels and electronics for the demersal fishery in the North Sea has a long time horizon. Thus, from the time 
that a fisherman decides to invest to the time when the investment takes place time passes. The opposite conclusion was arrived at for investment in gears.

\subsubsection{Disaggregated models.}

As in the aggregated model, we have no problems with autocorrelation and heteroscedasticity because the Durbin-Watson test is below 0.52 and the White test is below 11.2.

For investment in gears, model 2 performs best for all vessel types. A model without lags is not surprising for gears. Gears are a necessity for the fishing activity. An overview over the models of type 2 for investment in gears is given in Table 5 
Table 6: Disaggregated models for investment in gear

\begin{tabular}{|c|c|c|c|c|c|c|c|}
\hline & $\begin{array}{l}\text { Trawlers } \\
\text { between } 10- \\
18 \text { meters }\end{array}$ & $\begin{array}{l}\text { Trawlers } \\
\text { between } \\
18-24 \\
\text { meters } \\
\end{array}$ & $\begin{array}{l}\text { Trawlers } \\
\text { between } \\
24-40 \\
\text { meters } \\
\end{array}$ & $\begin{array}{l}\text { Trawlers } \\
\text { over } 40 \\
\text { meters }\end{array}$ & $\begin{array}{l}\text { Danish } \\
\text { Seiners }\end{array}$ & Netters & $\begin{array}{l}\text { Other } \\
\text { vessels }\end{array}$ \\
\hline Constant term & $7.17(0.22)$ & $\begin{array}{l}8.72 \\
(0.51)\end{array}$ & $\begin{array}{l}8.00 \\
(0.30)\end{array}$ & $\begin{array}{l}9.42 \\
(0.84)\end{array}$ & $\begin{array}{l}10.13 \\
(1.31)\end{array}$ & $\begin{array}{l}10.94 \\
(1.14)\end{array}$ & $\begin{array}{l}10.84 \\
(0.26)\end{array}$ \\
\hline Ln(tonnage) & $0.10(1.01)$ & $\begin{array}{l}0.08 \\
(0.99)\end{array}$ & $\begin{array}{l}0.07 \\
(0.94)\end{array}$ & $\begin{array}{l}0.06 \\
(0.76)\end{array}$ & $\begin{array}{l}0.03 \\
(0.69)\end{array}$ & $\begin{array}{l}0.03 \\
(0.58)\end{array}$ & $\begin{array}{l}0.01 \\
(0.09)\end{array}$ \\
\hline Ln(year) & $-1.11(-0.16)$ & $\begin{array}{l}-1.13 \\
(-0.21)\end{array}$ & $\begin{array}{l}-1.15 \\
(-0.34) \\
\end{array}$ & $\begin{array}{l}-1.14 \\
(-0.09) \\
\end{array}$ & $\begin{array}{l}-1.01 \\
(-0.17) \\
\end{array}$ & $\begin{array}{l}-0.99 \\
(-0.07) \\
\end{array}$ & $\begin{array}{l}-0.99 \\
(-0.08)\end{array}$ \\
\hline Ln(capital) & $0.21(5.73)$ & $\begin{array}{l}0.17 \\
(6.01)\end{array}$ & $\begin{array}{l}0.13 \\
(5.65)\end{array}$ & $\begin{array}{l}0.11 \\
(3.99)\end{array}$ & $\begin{array}{l}0.18 \\
(4.73)\end{array}$ & $\begin{array}{l}0.02 \\
(0.88)\end{array}$ & $\begin{array}{l}0.01 \\
(0.84)\end{array}$ \\
\hline $\operatorname{Ln}$ (price) & $0.07(2.01)$ & $\begin{array}{l}0.05 \\
(1.34) \\
\end{array}$ & $\begin{array}{l}0.1 \\
(2.99) \\
\end{array}$ & $\begin{array}{l}0.04 \\
(1.43) \\
\end{array}$ & $\begin{array}{l}0.05 \\
(1.64) \\
\end{array}$ & $\begin{array}{l}0.03 \\
(0.99) \\
\end{array}$ & $\begin{array}{l}0.02 \\
(0.76) \\
\end{array}$ \\
\hline Ln(interest) & $-0.69(-7.01)$ & $\begin{array}{l}-0.73 \\
(-7.14)\end{array}$ & $\begin{array}{l}-0.63 \\
(-6.01)\end{array}$ & $\begin{array}{l}-0.59 \\
(-4.99)\end{array}$ & $\begin{array}{l}-0.67 \\
(-4.79)\end{array}$ & $\begin{array}{l}-0.18 \\
(-0.88)\end{array}$ & $\begin{array}{l}-0.25 \\
(-1.12)\end{array}$ \\
\hline $\mathrm{D}_{1996}$ & $0.11(1.01)$ & $\begin{array}{l}0.11 \\
(0.99)\end{array}$ & $\begin{array}{l}0.13 \\
(1.27)\end{array}$ & $\begin{array}{l}0.10 \\
(0.82)\end{array}$ & $\begin{array}{l}0.09 \\
(0.57)\end{array}$ & $\begin{array}{l}0.02 \\
(0.34)\end{array}$ & $\begin{array}{l}0.09 \\
(0.65)\end{array}$ \\
\hline $\mathrm{D}_{1997}$ & $0.13(1.34)$ & $\begin{array}{l}0.14 \\
(1.66)\end{array}$ & $\begin{array}{l}0.13 \\
(1.37) \\
\end{array}$ & $\begin{array}{l}0.11 \\
(1.01)\end{array}$ & $\begin{array}{l}0.09 \\
(0.77)\end{array}$ & $\begin{array}{l}0.07 \\
(0.64)\end{array}$ & $\begin{array}{l}0.10 \\
(0.98)\end{array}$ \\
\hline $\mathrm{D}_{1998}$ & $0.07(0.67)$ & $\begin{array}{l}0.09 \\
(1.01)\end{array}$ & $\begin{array}{l}0.09 \\
(1.02)\end{array}$ & $\begin{array}{l}0.07 \\
(0.65)\end{array}$ & $\begin{array}{l}0.09 \\
(1.34)\end{array}$ & $\begin{array}{l}0.06 \\
(1.01)\end{array}$ & $\begin{array}{l}0.11 \\
(1.14)\end{array}$ \\
\hline $\mathrm{D}_{1999}$ & $0.17(1.73)$ & $\begin{array}{l}0.11 \\
(1.17)\end{array}$ & $\begin{array}{l}0.11 \\
(1.01)\end{array}$ & $\begin{array}{l}0.15 \\
(1.53)\end{array}$ & $\begin{array}{l}0.09 \\
(1.01)\end{array}$ & $\begin{array}{l}0.06 \\
(1.16)\end{array}$ & $\begin{array}{l}0.11 \\
(0.97)\end{array}$ \\
\hline $\mathrm{D}_{2000}$ & $0.07(0.69)$ & $\begin{array}{l}0.03 \\
(0.35)\end{array}$ & $\begin{array}{l}0.08 \\
(0.99)\end{array}$ & $\begin{array}{l}0.06 \\
(0.72)\end{array}$ & $\begin{array}{l}0.03 \\
(0.26)\end{array}$ & $\begin{array}{l}0.02 \\
(1.13\end{array}$ & $\begin{array}{l}0.03 \\
(0.38)\end{array}$ \\
\hline $\mathrm{D}_{2001}$ & $-0.02(-0.34)$ & $\begin{array}{l}0.00 \\
(0.17) \\
\end{array}$ & $\begin{array}{l}-0.00 \\
(-0.03) \\
\end{array}$ & $\begin{array}{l}-0.01 \\
(-0.16)\end{array}$ & $\begin{array}{l}0.03 \\
(0.34) \\
\end{array}$ & $\begin{array}{l}0.04 \\
(0.51)\end{array}$ & $\begin{array}{l}0.02 \\
(0.17) \\
\end{array}$ \\
\hline $\mathrm{D}_{2002}$ & $0.10(0.66)$ & $\begin{array}{l}0.13 \\
(1.11)\end{array}$ & $\begin{array}{l}0.09 \\
(0.89)\end{array}$ & $\begin{array}{l}0.10 \\
(0.64)\end{array}$ & $\begin{array}{l}0.10 \\
(0.72)\end{array}$ & $\begin{array}{l}0.09 \\
(0.73)\end{array}$ & $\begin{array}{l}0.10 \\
(0.57)\end{array}$ \\
\hline $\mathrm{D}_{2003}$ & $0.03(0.27)$ & $\begin{array}{l}0.05 \\
(0.37) \\
\end{array}$ & $\begin{array}{l}0.01 \\
(0.09) \\
\end{array}$ & $\begin{array}{l}0.00 \\
(0.05) \\
\end{array}$ & $\begin{array}{l}0.04 \\
(1.36) \\
\end{array}$ & $\begin{array}{l}-0.00 \\
(-0.02) \\
\end{array}$ & $\begin{array}{l}0.00 \\
(0.07)\end{array}$ \\
\hline $\mathrm{D}_{2004}$ & $0.08(0.87)$ & $\begin{array}{l}0.09 \\
(0.87)\end{array}$ & $\begin{array}{l}0.09 \\
(1.34)\end{array}$ & $\begin{array}{l}0.10 \\
(0.87)\end{array}$ & $\begin{array}{l}0.09 \\
(0.76)\end{array}$ & $\begin{array}{l}0.10 \\
(0.84)\end{array}$ & $\begin{array}{l}0.10 \\
(0.83)\end{array}$ \\
\hline $\mathrm{R}^{2}$ & 0.59 & 0.58 & 0.60 & 0.61 & 0.48 & 0.28 & 0.27 \\
\hline $\begin{array}{l}\text { Durbin-Watson } \\
\text { test }\end{array}$ & 0.38 & 0.51 & 0.49 & 0.47 & 0.36 & 0.47 & 0.52 \\
\hline White test & 10.8 & 7.4 & 10.5 & 10.7 & 11.2 & 7.4 & 8.9 \\
\hline
\end{tabular}

Note: t-values are given in parenthesis

For trawlers, the constant tern is generally lower than for Danish Seiners and netters. This implies that trawlers have a lower level of investment than Danish Seiners and netters. For trawlers and Danish Seiners, $\mathrm{R}^{2}$ is reasonable high while $\mathrm{R}^{2}$ is low for netters and other vessels. In addition, capital and interest is significant for Danish Seiners and trawlers while none of these variables are 
significant for other vessels for the demersal fishery in the North Sea. Also, price is significant for trawlers between 10-18 meters and trawlers between 24-40 meters. However, there is an important difference between trawlers, Danish Seiners and netters. For trawlers and Danish Seiners the estimated parameters for interest and capital is approximately the same as in the aggregated model, while the parameters in front of capital and interest in smaller for netters. This indicates that for netters is would be an advantage to estimate a disaggregated model. The disaggregated model would give us additional information about investment behaviour for netters.

A difference arises between the aggregated and disaggregated models. In the disaggregated models the variance for the estimated parameters is lower than in the aggregated model. This may be seen from the t-values in table 4 and 6 . The t-values are approximately the same but the number of observations is lower in Table 6. Thus, the variance is lower in the disaggregated model. However, this conclusion is not surprising. In the disaggregated model the variation between is smaller than in the aggregated model. Thus, the variance is smaller in the disaggregated model.

The significance of the capital stock, interest rate and output price index indicate that these variables important drivers for investment in gears for trawlers and Danish Seiners. We can not identify any drivers for investment in gears for other vessels and netters. That the models for Danish Seiners and trawlers perform well while the models for netters and other vessels perform poor may look surprising but the result has a natural explanation. Trawlers and Danish Seiners are reasonable large vessels and for such vessels economic factors may explain actions. Thus, when explaining investment behaviour, interest and capital are important factors. Contrary to this, netters and other vessels are small boats and here economic factors may not explain behaviour. Thus, interest and capital are insignificant. With respect to investments in machinery, vessel and electronics we, as in the aggregated model, obtain the best results by aggregating the categories to investment in other things than gears. Again model 4 gives the best results and this result is expected because there may be lags in connection with investment in vessels, machinery and electronics. Table 7 gives an overview over the results. 
Table 7: Disaggregated models for investment in other things than gears

\begin{tabular}{|c|c|c|c|c|c|c|c|}
\hline & $\begin{array}{l}\text { Trawlers } \\
\text { between } 10- \\
18 \text { meters }\end{array}$ & $\begin{array}{l}\text { Trawlers } \\
\text { between } \\
18-24 \\
\text { meters }\end{array}$ & $\begin{array}{l}\text { Trawlers } \\
\text { between } \\
24-40 \\
\text { meters }\end{array}$ & $\begin{array}{l}\text { Trawlers } \\
\text { over } 40 \\
\text { meters }\end{array}$ & $\begin{array}{l}\text { Danish } \\
\text { Seiners }\end{array}$ & Netters & $\begin{array}{l}\text { Other } \\
\text { vessels }\end{array}$ \\
\hline Constant term & $-69.4(-1.01)$ & $\begin{array}{l}-52.7 \\
(-0.91)\end{array}$ & $\begin{array}{l}-67.1 \\
(-0.81)\end{array}$ & $\begin{array}{l}-72.6 \\
(-1.21)\end{array}$ & $\begin{array}{l}-24.7 \\
(-0.41)\end{array}$ & $\begin{array}{l}-43.6 \\
(-0.67)\end{array}$ & $\begin{array}{l}-42.1 \\
(-0.67)\end{array}$ \\
\hline Ln(tonnage) & $0.51(0.82)$ & $\begin{array}{l}0.49 \\
(0.78)\end{array}$ & $\begin{array}{l}0.44 \\
(0.71)\end{array}$ & $\begin{array}{l}0.49 \\
(0.87)\end{array}$ & $\begin{array}{l}0.48 \\
(0.81)\end{array}$ & $\begin{array}{l}0.43 \\
(0.67)\end{array}$ & $\begin{array}{l}0.47 \\
(0.79)\end{array}$ \\
\hline Ln(year) & $-0.11(-1.25)$ & $\begin{array}{l}-0.09 \\
(-1.12)\end{array}$ & $\begin{array}{l}-0.09 \\
(-0.97)\end{array}$ & $\begin{array}{l}-0.10 \\
(-1.11)\end{array}$ & $\begin{array}{l}-0.09 \\
(-0.99)\end{array}$ & $\begin{array}{l}-0.08 \\
(-0.98)\end{array}$ & $\begin{array}{l}-0.08 \\
(-0.97)\end{array}$ \\
\hline Ln(capital) & $0.00(0.97)$ & $\begin{array}{l}0.03 \\
(1.27)\end{array}$ & $\begin{array}{l}0.00 \\
(1.00)\end{array}$ & $\begin{array}{l}0.00 \\
(0.90)\end{array}$ & $\begin{array}{l}0.02 \\
(1.24)\end{array}$ & $\begin{array}{l}0.01 \\
(1.18)\end{array}$ & $\begin{array}{l}0.00 \\
(0.86)\end{array}$ \\
\hline Ln(price) & $0.09(0.97)$ & $\begin{array}{l}0.10 \\
(0.95)\end{array}$ & $\begin{array}{l}0.11 \\
(1.07)\end{array}$ & $\begin{array}{l}0.11 \\
(1.07)-\end{array}$ & $\begin{array}{l}0.08 \\
(0.97)\end{array}$ & $\begin{array}{l}0.09 \\
(0.95)\end{array}$ & $\begin{array}{l}0.09 \\
(0.98)\end{array}$ \\
\hline Ln(interest) & $-0.14(-0.21)$ & $\begin{array}{l}-0.19 \\
(-0.35)\end{array}$ & $\begin{array}{l}-0.19 \\
(-0.36)\end{array}$ & $\begin{array}{l}-0.14 \\
(-0.27)\end{array}$ & $\begin{array}{l}-0.17 \\
(-0.28)\end{array}$ & $\begin{array}{l}-0.11 \\
(-0.18)\end{array}$ & $\begin{array}{l}-0.15 \\
(-0.24)\end{array}$ \\
\hline Ln(tonnage) $)_{-1}$ & $1.18(2.73)$ & $\begin{array}{l}1.13 \\
(2.27)\end{array}$ & $\begin{array}{l}1.11 \\
(2.26)\end{array}$ & $\begin{array}{l}1.11 \\
(2.31)\end{array}$ & $\begin{array}{l}1.27 \\
(3.45)\end{array}$ & $\begin{array}{l}1.23 \\
(3.01)\end{array}$ & $\begin{array}{l}0.59 \\
(1.09)\end{array}$ \\
\hline $\operatorname{Ln}(\text { year })_{-1}$ & $-0.51(-1.11)$ & $\begin{array}{l}-0.50 \\
(-1.11)\end{array}$ & $\begin{array}{l}-0.51 \\
(-1.14)\end{array}$ & $\begin{array}{l}-0.53 \\
(-1.27)\end{array}$ & $\begin{array}{l}-0.56 \\
(-1.39)\end{array}$ & $\begin{array}{l}-0.43 \\
(-1.32)\end{array}$ & $\begin{array}{l}-0.44 \\
(-0.94)\end{array}$ \\
\hline Ln(capital $)_{-1}$ & $0.23(7.79)$ & $\begin{array}{l}0.18 \\
(5.71)\end{array}$ & $\begin{array}{l}0.25 \\
(8.67)\end{array}$ & $\begin{array}{l}0.21 \\
(8.01)\end{array}$ & $\begin{array}{l}0.22 \\
(7.01)\end{array}$ & $\begin{array}{l}0.08 \\
(1.65)\end{array}$ & $\begin{array}{l}0.09 \\
(1.74)\end{array}$ \\
\hline $\operatorname{Ln}(\text { price })_{-1}$ & $0.10(0.87)$ & $\begin{array}{l}0.12 \\
(1.11)\end{array}$ & $\begin{array}{l}0.13 \\
(1.02)\end{array}$ & $\begin{array}{l}0.13 \\
(1.17) \\
\end{array}$ & $\begin{array}{l}0.15 \\
(1.39) \\
\end{array}$ & $\begin{array}{l}0.07 \\
(0.67)\end{array}$ & $\begin{array}{l}0.09 \\
(0.77)\end{array}$ \\
\hline $\operatorname{Ln}(\text { interest })_{-1}$ & $-0.34(-4.01)$ & $\begin{array}{l}-0.27 \\
(-3,18)\end{array}$ & $\begin{array}{l}-0.28 \\
(-3.08)\end{array}$ & $\begin{array}{l}-0.28 \\
(-3.36)\end{array}$ & $\begin{array}{l}-0.33 \\
(-4.07)\end{array}$ & $\begin{array}{l}-0.10 \\
(-1.34)\end{array}$ & $\begin{array}{l}-0.09 \\
(-0.99)\end{array}$ \\
\hline $\mathrm{D}_{1996}$ & $0.07(0.63)$ & $\begin{array}{l}0.13 \\
(1.19)\end{array}$ & $\begin{array}{l}0.10 \\
(0.83)\end{array}$ & $\begin{array}{l}0.11 \\
(0.94)\end{array}$ & $\begin{array}{l}0.12 \\
(1.03)\end{array}$ & $\begin{array}{l}0.10 \\
(0.87)\end{array}$ & $\begin{array}{l}0.10 \\
(0.77)\end{array}$ \\
\hline $\mathrm{D}_{1997}$ & $0.05(0.74)$ & $\begin{array}{l}0.02 \\
(0.54) \\
\end{array}$ & $\begin{array}{l}0.05 \\
(0.57) \\
\end{array}$ & $\begin{array}{l}0.08 \\
(0.91) \\
\end{array}$ & $\begin{array}{l}0.03 \\
(0.61) \\
\end{array}$ & $\begin{array}{l}0.02 \\
(0.57)\end{array}$ & $\begin{array}{l}0.05 \\
(0.69)\end{array}$ \\
\hline $\mathrm{D}_{1998}$ & $0.11(1.27)$ & $\begin{array}{l}0.13 \\
(1.34)\end{array}$ & $\begin{array}{l}0.15 \\
(1.52)\end{array}$ & $\begin{array}{l}0.11 \\
(1.29)\end{array}$ & $\begin{array}{l}0.13 \\
(1.29)\end{array}$ & $\begin{array}{l}0.11 \\
(1.21)\end{array}$ & $\begin{array}{l}0.11 \\
(1.22)\end{array}$ \\
\hline $\mathrm{D}_{1999}$ & $0.05(0.90)$ & $\begin{array}{l}0.06 \\
(1.01)\end{array}$ & $\begin{array}{l}0.05 \\
(1.09)\end{array}$ & $\begin{array}{l}0.03 \\
(0.71)\end{array}$ & $\begin{array}{l}0.02 \\
(0.87)\end{array}$ & $\begin{array}{l}0.04 \\
(1.00)\end{array}$ & $\begin{array}{l}0.04 \\
(0.99)\end{array}$ \\
\hline $\mathrm{D}_{2000}$ & $-0.14(-1.01)$ & $\begin{array}{l}-0.10 \\
(-0.87)\end{array}$ & $\begin{array}{l}-0.15 \\
(-1.10)\end{array}$ & $\begin{array}{l}-0.15 \\
(-1.09)\end{array}$ & $\begin{array}{l}-0.15 \\
(-1.07)\end{array}$ & $\begin{array}{l}-0.12 \\
(-1.01)\end{array}$ & $\begin{array}{l}-0.11 \\
(-0.95)\end{array}$ \\
\hline $\mathrm{D}_{2001}$ & $0.16(1.51)$ & $\begin{array}{l}0.22 \\
(1.89)\end{array}$ & $\begin{array}{l}0.23 \\
(2.07)\end{array}$ & $\begin{array}{l}0.18 \\
(1.54)\end{array}$ & $\begin{array}{l}0.21 \\
(1.78)\end{array}$ & $\begin{array}{l}0.21 \\
(1.81)\end{array}$ & $\begin{array}{l}0.20 \\
(1.78)\end{array}$ \\
\hline $\mathrm{D}_{2002}$ & $0.20(1.78)$ & $\begin{array}{l}0.20 \\
(1.75)\end{array}$ & $\begin{array}{l}0.20 \\
(1.74)\end{array}$ & $\begin{array}{l}0.23 \\
(2.03)\end{array}$ & $\begin{array}{l}0.16 \\
(0.87)\end{array}$ & $\begin{array}{l}0.21 \\
(0.73)\end{array}$ & $\begin{array}{l}0.18 \\
(0.79)\end{array}$ \\
\hline $\mathrm{D}_{2003}$ & $-0.11(-2.44)$ & $\begin{array}{l}-0.12 \\
(-2.56)\end{array}$ & $\begin{array}{l}-0.11 \\
(-2.48)\end{array}$ & $\begin{array}{l}-0.12 \\
(-2.57)\end{array}$ & $\begin{array}{l}-0.14 \\
(-2.84)\end{array}$ & $\begin{array}{l}-0.11 \\
(-2.56)\end{array}$ & $\begin{array}{l}-0.14 \\
(-2.78)\end{array}$ \\
\hline $\mathrm{D}_{2004}$ & $0.16(1.14)$ & $\begin{array}{l}0.16 \\
(1.34)\end{array}$ & $\begin{array}{l}0.14 \\
(1.03)\end{array}$ & $\begin{array}{l}0.13 \\
(1.09)\end{array}$ & $\begin{array}{l}0.15 \\
(1.22)\end{array}$ & $\begin{array}{l}0.11 \\
(0.98)\end{array}$ & $\begin{array}{l}0.13 \\
(1.24)\end{array}$ \\
\hline $\mathrm{R}^{2}$ & 0.61 & 0.62 & 0.66 & 0.63 & 0.61 & 0.31 & 0.33 \\
\hline Durbin-Watson & 0.18 & 0.37 & 0.09 & 0.35 & 0.34 & 0.19 & 0.18 \\
\hline
\end{tabular}




\begin{tabular}{|l|l|l|l|l|l|l|l|}
\hline test & & & & & & & \\
\hline White test & 6.1 & 8.8 & 10.3 & 9.5 & 7.9 & 7.1 & 8.3 \\
\hline
\end{tabular}

Note: $\mathrm{t}$-values are given in parenthesis

The result for investment in other things than gears is analogous to the results for investment in gears. The explanatory power is high for trawlers and Danish Seiners and low for other vessels and netters. Trawlers have a lower level of investment because the constant term is lower. None of the parameters is significant for other vessels and netters. The insignificant parameters for other vessels and netters imply that we can not identify a driver for investment for theses categorise. Capital 1 , interest $_{-1}$ and tonnage ${ }_{-1}$ is significant for trawlers and Danish Seiners. This implies that these variables are drivers for investment on other things than gear. For netters it would be an advantage to estimate a disaggregated model because the parameters differ a lot from the parameters in front of the variables. In addition, the variance for the estimated parameters is lower in the disaggregated model. This conclusion is not surprising because vessels are more homogeneous in the disaggregated model.

\section{Conclusion}

This paper analyse drivers for investment in the demersal fishery in the North Sea. The North Sea demersal fishery has been regulated with rations and annual allocations and investments influence the optimal allocation on these instruments to vessels.

In an aggregated model with all fleet segments included we show that interest rates and capital stocks are important determinants for investments. Trawlers, generally, invest less than Danish Seiners. For the aggregated model investments in gears are best explained using a model with present variables while investments in machinery, electronics and vessels are best explained using lagged variables. This conclusion is not surprising. Investments in gears have a short time horizon because gears are necessary for the fishing activity. Contrary to this, investments in other things than gears have a longer time horizon.

We also estimate a disaggregated model where an investment function is estimated separately for each fleet segment. For Danish Seiners and trawlers we reach the same results as for the aggregated model. Thus, the interest rate and capital stock is significant. However, for netters and other vessels, none of the variables are significant. This result is logical. Danish Seiners and trawlers are large vessels and economic variables, like capital stock and interest rate, may explain the investment behaviour. Contrary, netters are smaller vessels and here economic variables may be a poor 
predictor of behaviour. As for the aggregated model, we also reach the result in the disaggregated model that investment in gears is explained by current variables while investments in other things than gears are governed by lagged variables. Thus, this result is robust. Another result is that the variance of the estimated parameters is lower in the disaggregated models. This result is natural because the vessels in the disaggregated models are more homogeneous.

For future research empirical studies of investment behaviour are important. Here other species and seas must be analysed. In this way we can see if the conclusions in the present paper generalise to other circumstances. Another interesting area for future research is change in investment behaviour under large shifts in the regulatory approach. For example, a variant of ITQs was implemented in 2007 in the Danish demersal fishery and it could be of interest to study changes in investment behaviour as a consequence of introducing ITQs. Here we could make use of the tools in policy analysis. 
Literature

Anon. (2007): Report of the Working Group on the Assessment of Demersal Stock in the North Sea and Skagerrak, ICES.

Arnason, R. (2008): Iceland's ITQ System Creates New Wealth, The Electronic Journal of Sustainable Development, 1, pp. 35-41.

Brown, G. (1974): An Optimal Program for Managing Common Property Resources with Congestion Externalities, Journal of Political Economy, 82, pp. 405-422.

Clark, C.W. (1990): Mathematical Bioeconomics. The Optimal Management of Renewable Resources, New York: John Wiley and Sons.

Clark, C.W., Clarke, F.H. and Munro, G.R. (1979): The Optimal Exploitation of Renewable Resource Stocks: Problems of Irreversible Investment, Econometrica, 47, pp. 25-47.

Clark, C.W. and Munro, G.R. (1975): The Economics of Fishing and Modern Capital Theory: A Simplified Approach, Journal of Environmental Economics and Management, 2, pp. 92-106.

Conrad, J.M. and Clark, C.W. (1991): Natural Resource Economics. Notes and Problems, Cambridge: Cambridge University Press.

Jorgensen, D. (1971): Econometric Studies of Investment Behaviour: A Survey, Journal of Economic Literature, 9, pp. 1111-1147.

Kirkley, J. and Squires, D. (1999): Measuring Capacity and Capacity Utilisation in Fisheries, FAO Fisheries Technical Paper, FAO: Rome.

Nostbakken, L. (2009): Capacity Adjustment and Drivers of Investment in an Industry Regulated with Tradable Output Quotas, Submitted to ???.

Reed, W.J. (1974): A Stochastic Model for Economic Management of a Renewable Resource, Mathematical Bioscience, 22, pp. 313-337.

Smith, V.L. (1968): Economics of Production from Natural Resources, American Economic Review, 58, pp. 409-432.

Smith, V.L. (1969): On Models of Commercial Fishing, Journal of Political Economy, 77, pp. 181198.

Wilen, J. (1976): Common Property Resources and the Dynamics of Overexploitation: The Case of the North Pacific Fur Seal, PNRE paper 3, University of British Columbia.

Wilen, J (2000): Renewable Resource Economists: What Difference Have We Made, Journal of Environmental Economics and Management, 37, pp.229-239. 